\title{
The BioDARPA Concept
}

\author{
Ilya Klabukov \\ Sechenov First Moscow State Medical University, Institute for regenerative medicine, Moscow, Russia
}

ilya.klabukov@gmail.com

\begin{abstract}
The dramatic development of biomedical technologies inevitably raises a question of the increasing "gap" between basic biomedical discoveries and their use in clinical practice. Created in 1958 with the same purpose, DARPA has had to bridging the gap in defense technologies (mostly in rocket and radar sciences). Today we can talk about the relevance of the idea of "biomedical DARPA" (BioDARPA) as a concept of organizational design for priority research and development of emerging biotechnologies.
\end{abstract}

\section{INTRODUCTION}

Defense Advanced Research Projects Agency (DARPA) - the U.S. federal agency which mission is to maintain the technological superiority of the U.S. military and prevent technological surprise from harming the American national security (Dugan and Gabriel, 2013; Munos, 2008). The DARPA was created in response to Soviet Rocket Science Challenge in 1958, and up to now reconciles technological ambitions and hard reality (Klabukov et al., 2014).

The ideas of realization of a darpa-like agency are formulated for microelectronics (Alic and Robyn, 1990), energy (Bonvillian and van Atta, 2011) and since $1990^{\text {th }}$ also for biomedicine (Cook-Deegan, 1997). This was especially critical for projects that were too radical for traditional institutions like the National Institutes of Health (NIH) and the National Science Foundation (NSF) (Marshall, 1997). 
Since early $2000^{\text {th }}$ biological projects have become the place in Agency programs (Eisenstadt, 2001) and the biomedical DARPA challenge was formulated (Greenberg, 2003).

In 2014 the Agency created a new Biological Technology Office (BTO) to emphasized the new importance of biomedical technology (Laursen, 2014) and was allowed experts to talk about the phenomenon of "military-bioscience complex" (Reardon, 2015). The office focuses on basic and applied research in the areas of gene editing, biotechnologies, neurosciences and synthetic biology - from powered exoskeletons for soldiers to brain implants that can control mental disorders (Reardon, 2015). The BTO is responsible for all neurotechnology, humanmachine interface, human performance, infectious disease, and synthetic biology programs within the Agency.

\section{CHALLENGES}

In the $20^{\text {th }}$ century there were many challenges that stimulated the intensification of scientific and technical thought: the Manhattan Project, the Sputnik Challenge, the Apollo program. Among today's global challenges it's especially possible to distinguish the phenomena "colonization of space" and "immortality of the human". And if the first problem is still far from the full-scale embodiment, then the second one can be already formulated.

The Immortality of the Human project represents a complex problem which solution will demand permission of the whole group of technological tasks, many of which are listed in the collection of tasks in engineering biology (Klabukov, 2016). Among the necessary for realization of concepts of technological decisions it is possible to note "life-like test-stand", "test-range for bioengineered devices", "pharmaceutical foundry in the Gut", "molecular scalpel for fetal and postnatal surgery in vivo" (Klabukov, 2017), “biological Internet” (Klabukov, 2015), "humanized animal models", "organ-on-chip for clinical trials", "bio-decks for human enhancement", etc.

Good example of transhumanistic challenges are presented in the Regenerative Medicine Roadmap 2.0 (Batin et al., 2010) and the Roadmap to Immortality (Fig. 1) (Batin et al., 2013). 


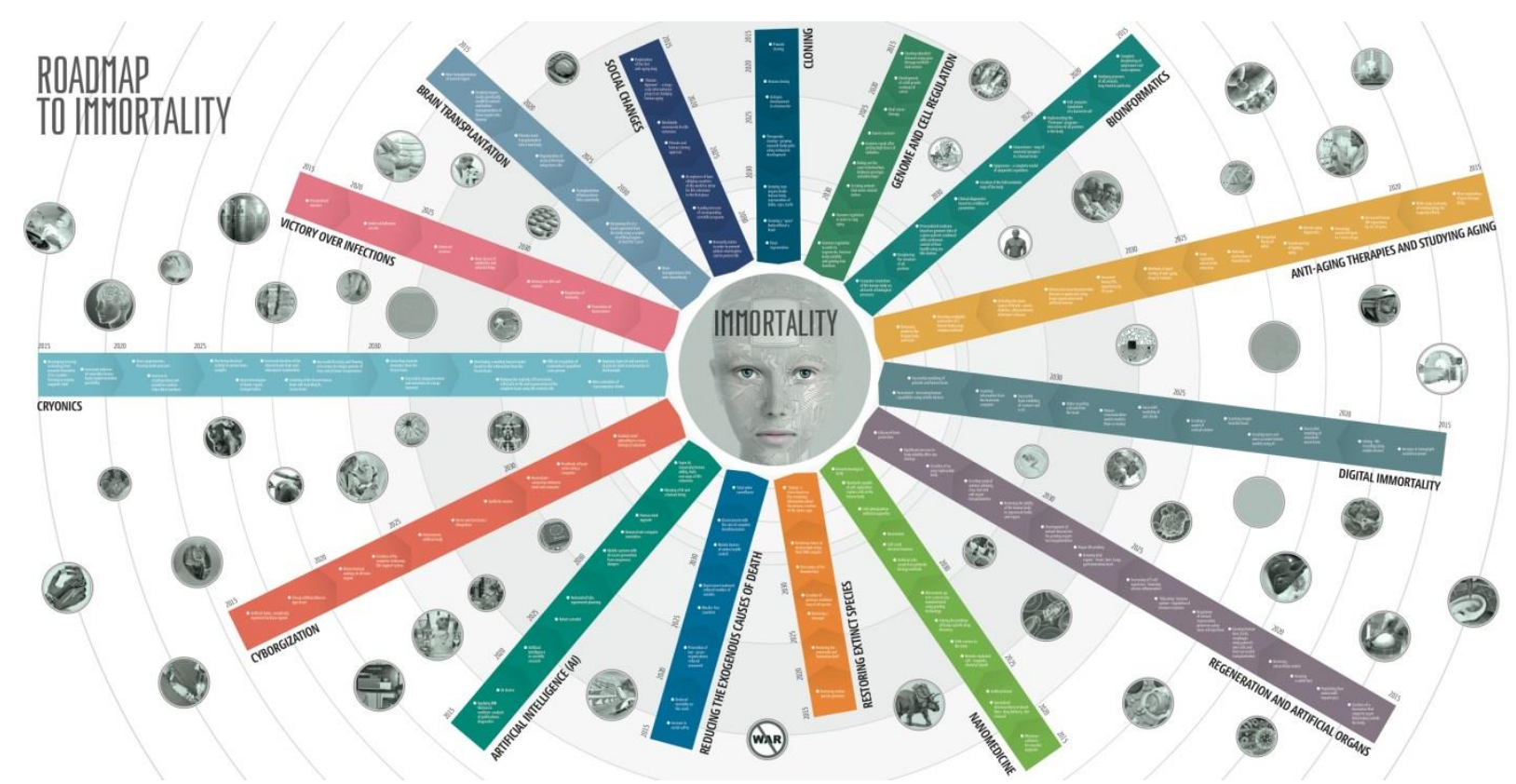

Figure 1. Roadmap to Immortality (C) Mikhail Batin, Maria Konovalenko, Alexey Turchin, 2013.*

The Roadmap to Immortality includes cryonics, regenerative medicine, artificial intelligence, cyborgization, and more terms of the future. These challenges can be grouped by common themes:

- Human longevity as a way for personal immortality;

- Medical "test-ranges" as an alternative for standard clinical and preclinical trials for biodrugs and artificial organs;

- Biological Internet;

- and other "the bio-tasks of dream" (like ones presented in "The Engineering Biology Problems Book", doi:10.2139/ssrn.2898429).

\section{DRIVERS}

\section{Political and Public activity}

The industry has a very important social and business activity of individuals such as Drew Andy (UC Berkeley, professor), Melissa Rods (Lockheed Martin, systems engineer) and

\footnotetext{
* Roadmap to Immortality. https://mariakonovalenko.files.wordpress.com/2013/01/roadmap_immortality_eng.pdf
} 
even Edward You (FBI, supervisory special agent), Elon Musk (SpaceX, entrepreneur and techgov communicator).

In 2015 by congresswoman Eddie Bernice Johnson was initiated the "H.R.591. Engineering Biology Research and Development Act of 2015" to implement a National Engineering Biology Research and Development Program to advance societal well-being, national security, and economic productivity and competitiveness through: 1) advancing areas of research at the intersection of the biological, physical, and information sciences and engineering; 2) supporting social science research that advances the field of engineering biology and contributes to the adoption of new products, processes, and technologies; 3) expanding the number of researchers, educators, and students with engineering biology training; 4) accelerating the translation and commercialization of engineering biology research and development by the private sector; 5) and improving the interagency planning and coordination of federal government activities related to engineering biology (Johnson, 2015).

\section{Professional communities and committees}

Professional communities and committees are presented of the Standards Coordinating Body For Cellular/Gene and Regenerative Therapies and Cell-Based Drug Discovery (Hayakawa et al., 2016), Synthetic Biology Open Language Developer's Group (Contreras et al., 2015), iGEM Foundation (Shetty et al., 2008), the NIST's public activity, Department of Defense workgroups, etc.

\section{Public activities}

The International movement for Life Extension has a bright and long-term history (Stambler, 2012). Now the public movements are represented by various activities like the “Transhumanist party” by Zoltan Istvan (Lee, 2016), Michael Batin's transhumanists community (Batin, 2015), Dmitry Itskov’s “2045 Initiative” (Petersen, 2015), Craig Venter Institute’s startups (Shimasaki, 2014), KrioRus company (Bernstein, 2015), etc. 


\section{ECONOMICS}

The development of advanced technology sectors has always required the robust economic base like as long-term Pentagon contracts for microelectronics and radar technologies in Silicon Valley (Steinbock, 2014) or the Internet economy boom for the "web 2.0" applications investments.

The economic base of biomedical technologies is only at the beginning of its development. Combination of programs of Department of Health and Human Services (DHHS), Military Health System (MHS), DTRA, BARDA (Schoch-Spana, 2012) with civil activities are not enough for sustainable development for biotechnological superiority. This poses a serious barrier to the development of the biomedical industry, but in the different plans and road maps is expected rapid growth in this market (HealthNet, Russia) to more than $\$ 1$ trillion by 2035 (Schubert, 2016).

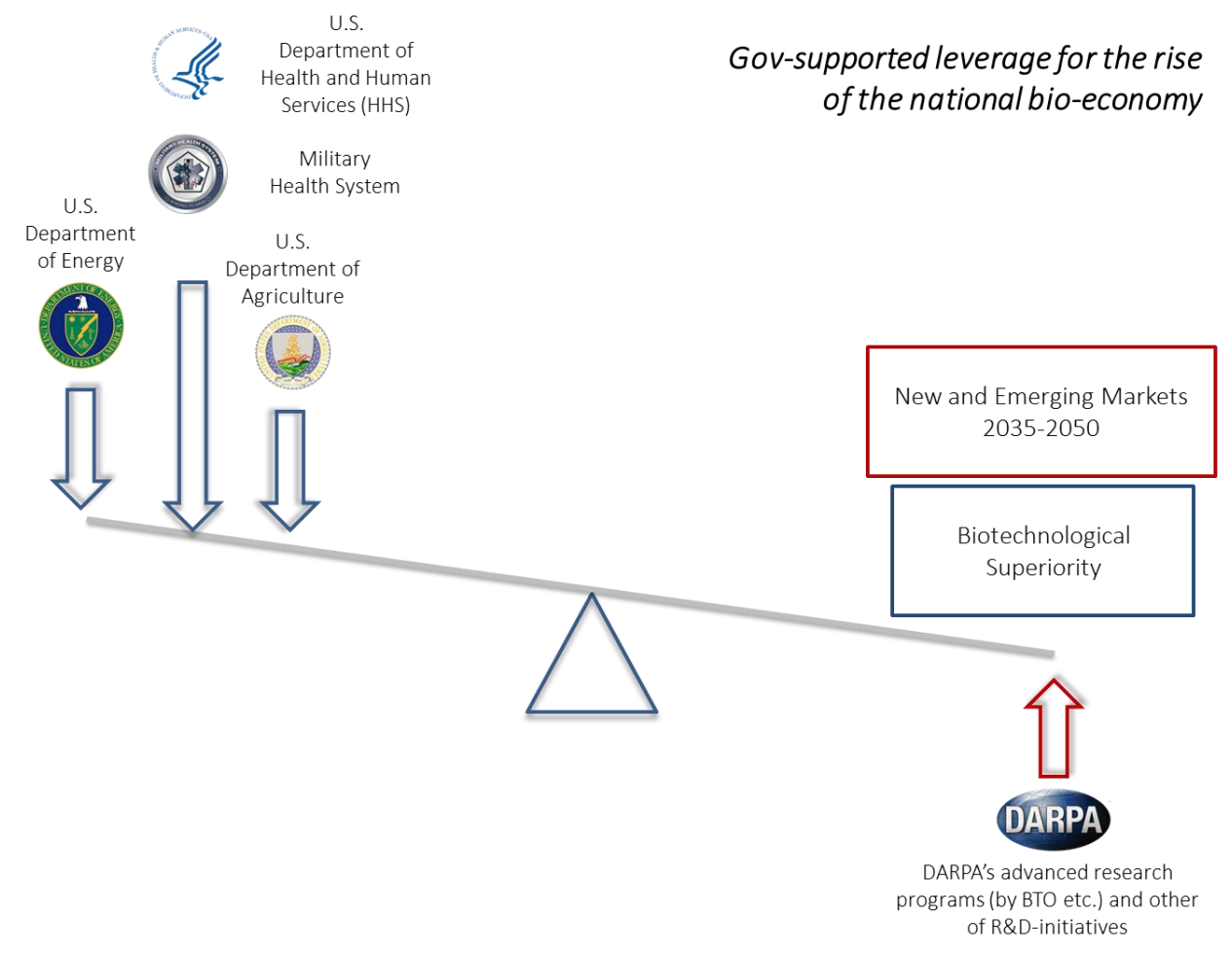

Figure 2. Government-supported leverage for the rise of national bio-economy (C) Ilya Klabukov, 2017. 
In the field of advanced biomedical technologies can be used a government-supported leverage to research and market stimulation both the key directions and related fields (Fig. 2).

\section{ORGANIZATION MODEL}

The previous attempts of realization of darpa-like models were implemented in the form of the government agencies (ARPA-E, i.e. Energy), the interrelated projects collaboration (HSARPA, i.e. homeland security), or even agency community (IARPA, i.e. intelligence).

Existing an experimental models of R\&D activities like the CIA's venture funds "In-QTel" (Lerner et al., 2005), "OnPoint Technologies" and other venture investment tools (Klabukov et al., 2012). In many ways, these tools are made possible by M\&A activity in the defense and aerospace sector in the mid-1990s.

In various discussions it was noted that technological development incentives could be: 1) funding mechanisms to support the early development phase of countermeasures (the "valley of death"); 2) creation of a "BioDARPA" that would invest in transformational bioresearch. Such research would be "project driven" and linked to identified national needs ("Roundtable discussion : when terror strikes--preparing an effective and immediate public health response," 2005).

- Development of shining-new Health and Wellness markets for personalized products ("markets for things that do not exist") (Connell, 2014);

- Establishment of a very early stage technology companies operates to creating future markets for things that do not exist (Connell, 2014). For examples of this "companies of hope" are the Lung Biotechnology Inc. (the United Therapeutics startup for produce a humanized organs), Synthetic Genomics, Inc. (Craig Venter's startup of attenuated viruses technologies for the vaccines production), Organovo Holdings, Inc. (3DBioprinting equipment and products), ViThera Pharmaceuticals, Inc. (geneticallyengineered probiotic bacteria and yeast for the delivery of therapeutic proteins in the 
human gastrointestinal tract), Cornell (genetically-engineered synanthropic bacteria to prevent of the cholera-associated pathologies), Synthorx (systems of synthesis of biologics and biofeedstocks based on a 6-letter genetic code), Amyris (synthetic biology bio-products), etc.

- Government-supported public programs for stimulation of investment activities and foster consumption;

- Increase a confidence in the market sector of new biomedical technology products (government regulation, industry standards, quality control).

Today the U.S. Governance Innovation System are presented in the think-tank corporations (RAND Corp., MITRE's Workgroups, Woodrow Wilson International Center), the National Laboratories (Lincoln Laboratory, Lawrence Livermore Laboratory, etc), the Defense Command and Wides (DARPA, Medical Command, etc.) and civil agencies (BARDA, NIST), the New age Industry firms like SpaceX and bio-startups, various Venture and M\&A funds (OnPoint Inc.), Non-profit organizations (100-Years Starship, IGEM Foundation), the Governance infrastructure networks (The Protein Capture Reagents Program, National Network for Manufacturing Innovation) and the Crowd networks (ARPA-E, IARPA Community).

The hypothetical formation and location of "BioDARPA Concept" in the U.S. Governance Innovation System are presented on Fig. 3. 


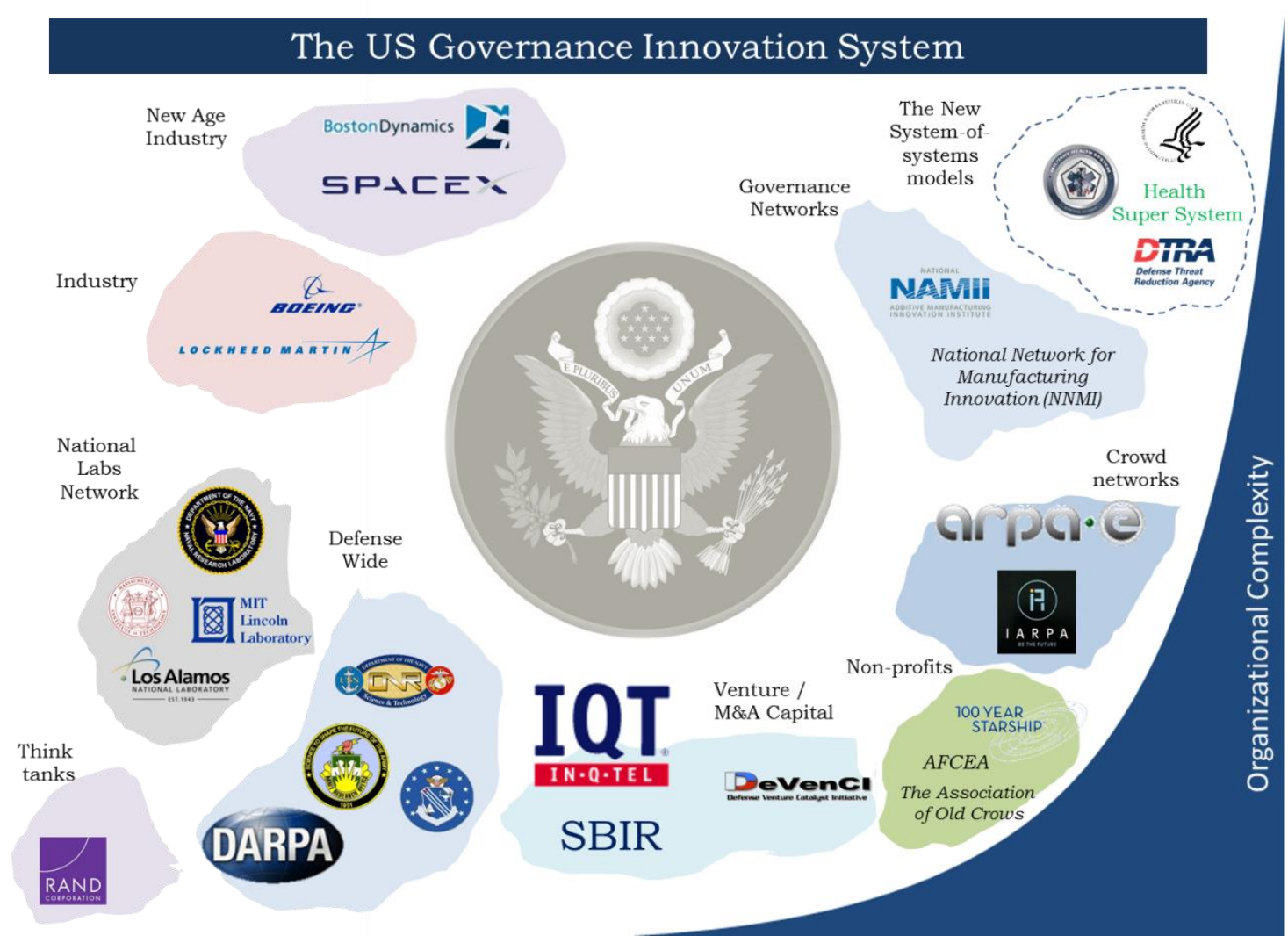

Figure 3. Hypothetical model of "BioDARPA Concept" in the U.S. Governance Innovation System. (C) Ilya Klabukov, 2017.

Supposed that new business models (pharmaceutical industry framework) such as precompetitive research, crowdsourcing, networked innovation, virtual companies, drug repurposing, and forced disruption (e.g., DARPA) are spreading and enriching the biomedical innovation ecosystem (Munos and Orloff, 2016).

The problem is noted that $90 \%$ of medical research stands to benefit only $10 \%$ of the population. While others dispute the numbers, there is little doubt that disparities exist in the global agenda for medical research (Mccarthy, 2015). This bring up a point to accelerate the translation into clinical practice that can be achieved by experimental clinical sites. 


\begin{tabular}{|c|c|c|}
\hline $\begin{array}{l}\text { Industry } \\
\text { DuPont, Amyris, Genomatica, } \\
\text { BioAmber, POET-DSM Advanced } \\
\text { Biofuels, Harvard Apparatus } \\
\text { Regenerative Technology, CRISPR } \\
\text { Therapeutics, Organovo, etc. }\end{array}$ & $\begin{array}{l}\text { Supporting } \\
\text { National Institutes of Health } \\
\text { Military Health System } \\
\text { Department of Energy (DOE) } \\
\text { Department of Agriculture (USDA) }\end{array}$ & $\begin{array}{l}\text { Advanced research } \\
\text { DARPA and other Defense-wides } \\
\text { National Aeronautics and Space } \\
\text { Administration (NASA) } \\
\text { National Science Foundation }\end{array}$ \\
\hline $\begin{array}{l}\text { Education } \\
\text { Massachusetts Institute of } \\
\text { Technology } \\
\text { University of California, Berkeley } \\
\text { High School System } \\
\text { Online educations (EdX, Coursera) }\end{array}$ & $\begin{array}{l}\text { Investment } \\
\text { Venture funds } \\
\text { Corporate invesntent }\end{array}$ & $\begin{array}{l}\text { Security } \\
\text { Federal Bureau of Investigation } \\
\text { Environmental Protection Agency } \\
\text { Food and Drug Administration (FDA) }\end{array}$ \\
\hline
\end{tabular}

Figure 4. BioDARPA’s Mosaic Exposome. (C) Ilya Klabukov, 2017.

BioDARPA's Super-system (system-of-systems) complexity can be realized as mosaic exposome (“cloud model”) around core organization system (Fig. 4).

\section{ETHICS}

It's obviously that needing for liberation of biology to biotech revolution (Bailey, 2005) but influence of traditional conservative forces is for the present quite big. The studies in human enhancement and synthetic biology ethics are need to addition of new Responsible Research and Innovation (RRI) concepts (Nerlich and McLeod, 2016). 


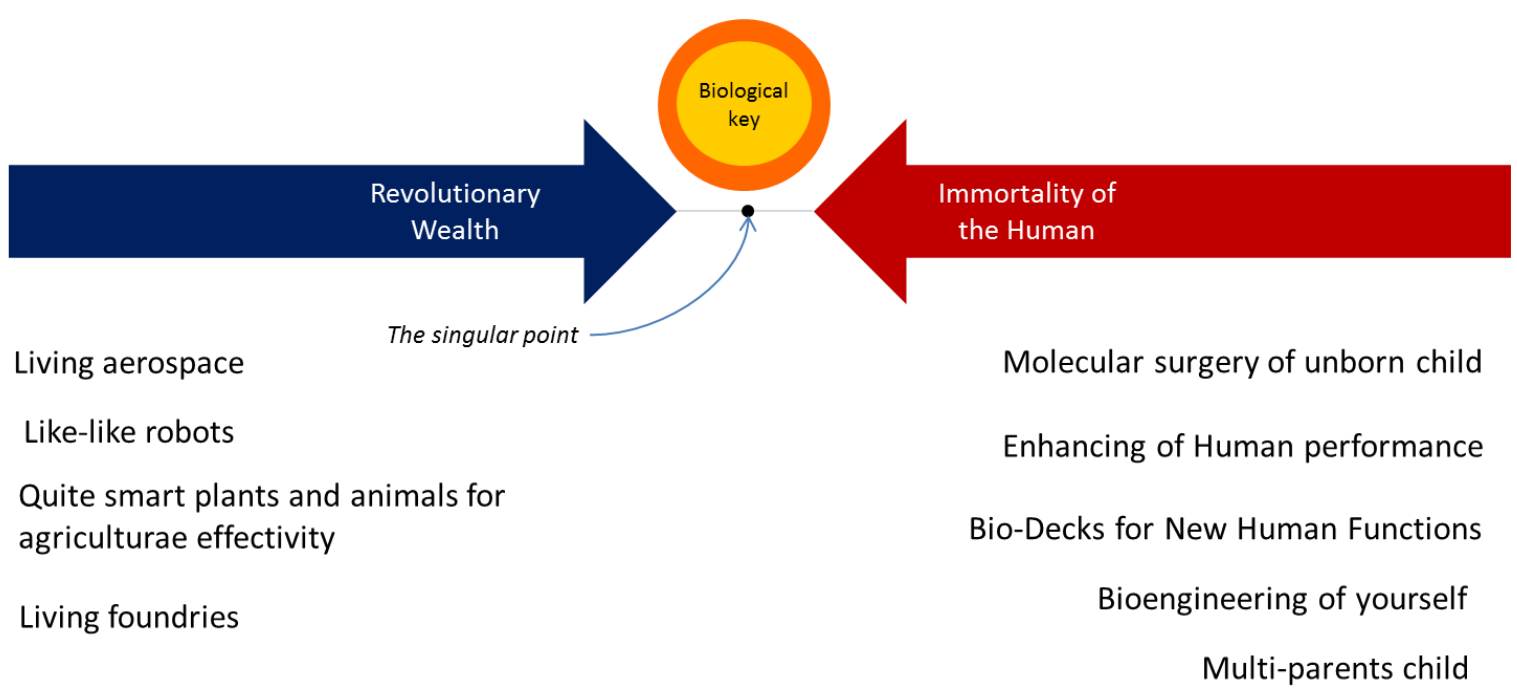

Figure 5. Conceptual fields of new biomedical breakthroughs: between Revolutionary Wealth and Immortality of the Human (c) Ilya Klabukov, 2017.

Further development of technologies for mass market production of organs in humanized animals edited using CRISPR/Cas9 system is associated with common models of "life" perception. It is necessary to overcome many more of ethical barriers (Fig. 5).

\section{CONCLUSION}

The BioDARPA Concept provides the advancing development and broadcasting in clinical practice of the advanced biomedical technologies. The problems of creation of this "firm" (or a cloud forms) are associated with the complexity of their constitution (system-ofsystems model), clear statement of the program goals (the White Book), source selection (both performers and consulting firms), staff recruitment, and location of the BioDARPA in the National Innovation System (both defense and civilian parts).

The ResearchGate Project Group "BioDARPA: Biomedical Breakthroughs and Superiority" ${ }^{\prime \dagger}$ is founded for data collect discussing on actual themes".

\footnotetext{
$\dagger$ "BioDARPA : Biomedical Breakthroughs and Superiority”. ResearchGate Project Group's Link: https://www.researchgate.net/project/BioDARPA-Biomedical-Breakthroughs-and-Superiority

\$nfortunately that’s some activities like popular twitter account (@BioDARPA) was banned by the trademark holder in 2014.
} 


\section{References}

Alic, J.A., Robyn, D., 1990. Designing a civilian DARPA. Optics and Photonics News 1, 17-22. https://doi.org/10.1364/OPN.1.5.000017

Bailey, R., 2005. Liberation biology: The scientific and moral case for the biotech revolution. Prometheus Books. Batin, M.A., 2015. The Immortality Doctrine. Biznes-Zhurnal 20-22.

Batin, M., Chistyakov, D., Kiseleva, E., Kokurina, E., Konovalenko, M., Macchiarini, P., Paltsev, M., Shkrob, M., Sprygin, A., Thomas, M., Tutukina, M., Ulasov, A., Vasiljev, A., Vorotelyak, C., 2010. Regenerative Medicine Roadmap 2.0.

Batin, M., Konovalenko, M., Turchin, A., 2013. Roadmap to Immortality.

Bernstein, A., 2015. Freeze, die, come to life: The many paths to immortality in post-Soviet Russia. American Ethnologist 42, 766-781. https://doi.org/10.1111/amet.12169

Bonvillian, W.B., van Atta, R., 2011. ARPA-E and DARPA: Applying the DARPA model to energy innovation. Journal of Technology Transfer 36, 469-513. https://doi.org/10.1007/s10961-011-9223-X

Connell, D., 2014. Creating markets for things that don't exist.

Contreras, J.L., Rai, A.K., Torrance, A.W., 2015. Intellectual property issues and synthetic biology standards. Nature biotechnology 33, 24-5. https://doi.org/10.1038/nbt.3107

Cook-Deegan, R.M., 1997. Does NIH Need a DARPA? Issues in Science and Technology 13, $25-28$.

Dugan, R.E., Gabriel, K.J., 2013. "Special Forces” Innovation: How DARPA attacks problems. Harvard Business Review 91, 74-84.

Eisenstadt, E., 2001. What Is DARPA Doing in Biology?, in: American Physical Society, Annual March Meeting, March 12-16, 2001 Washington State Convention Center. Seattle, p. Abstract \#J23.004.

Greenberg, D.S., 2003. A biomedical DARPA? Yes, but not at NIH: a cutting-edge research center would suffocate in the NIH's institutional quagmire. The Scientist 17, 52-53.

Hayakawa, T., Harris, I., Joung, J., Kanai, N., Kawamata, S., Kellathur, S., Koga, J., Lin, Y.-C., Maruyama, Y., McBlane, J., Nishimura, T., Renner, M., Ridgway, A., Salmikangas, P., Sakamoto, N., Sato, D., Sato, Y., Toda, Y., Umezawa, A., Werner, M., Wicks, S., 2016. Report of the International Regulatory Forum on Human Cell Therapy and Gene Therapy Products. Biologicals. https://doi.org/10.1016/j.biologicals.2016.06.002

Johnson, E.B., 2015. H.R.591. - Engineering Biology Research and Development Act of 2015.

Klabukov, I., 2017. Foundations for Molecular and Enzymatic Functional Surgery. Biotechnology eJournal 1. https://doi.org/10.2139/ssrn.2943526

Klabukov, I., 2016. Engineering Biology Problems Book. SSRN Electronic Journal 54. https://doi.org/10.2139/ssrn.2898429

Klabukov, I., 2015. DARPA-2016: On the rise of Biological Internet. Moscow. https://doi.org/10.13140/RG.2.2.15269.19689

Klabukov, I., Alekhin, M., Musienko, S., 2012. Venture Funds and Other Advanced Technologies for National Intelligence Services. https://doi.org/10.13140/RG.2.2.28827.87842

Klabukov, I., Alekhin, M., Nekhina, A., 2014. Review of DARPA FY2015 Research Programs. Innovation Practice eJournal 2. https://doi.org/10.2139/ssrn.2439081

Laursen, L., 2014. DARPA redesign. Nature Biotechnology 32, 509-509. https://doi.org/10.1038/nbt0614-509

Lee, N., 2016. The Transhumanist Platform and Interview with 2016 U.S. Presidential Candidate Zoltan Istvan, in: Google It. Springer New York, New York, NY, pp. 517-531. https://doi.org/10.1007/978-1-4939-6415-4_31

Lerner, J., Hardymon, F., Leamon, A., Book, K., 2005. In-Q-Tel.

Marshall, E., 1997. Too radical for NIH? Try DARPA. Science (New York, N.Y.) 275, 744-6. https://doi.org/10.1126/SCIENCE.275.5301.744

Mccarthy, M.P., 2015. Research and Reality: Towards Responsible Medical Research for Catholic Universities. Loyola University Chicago.

Munos, B., 2008. The DARPA Innovation Model, Creativity.

Munos, B.H., Orloff, J.J., 2016. Disruptive Innovation and Transformation of the Drug Discovery and Development Enterprise.

Nerlich, B., McLeod, C., 2016. The dilemma of raising awareness “responsibly.” EMBO Rep. 17, 481-485. https://doi.org/10.15252/embr.201541853

Petersen, A., 2015. Hope of Immortality, in: Hope in Health. Palgrave Macmillan UK, London, pp. 109-139. https://doi.org/10.1057/9781137313867_5

Reardon, S., 2015. The military-bioscience complex. Nature 522, 142-4. https://doi.org/10.1038/522142a

Roundtable discussion : when terror strikes--preparing an effective and immediate public health response, 2005.

Schoch-Spana, M., 2012. The People's Role in U.S. National Health Security: Past, Present, and Future. Biosecurity and Bioterrorism: Biodefense Strategy, Practice, and Science 10, 77-88.

https://doi.org/10.1089/bsp.2011.0108

Schubert, J., 2016. Russia's “National Technology Initiative.” Moscow.

Shetty, R.P., Endy, D., Knight, T.F., 2008. Engineering BioBrick vectors from BioBrick parts. Journal of biological engineering 2, 5. https://doi.org/10.1186/1754-1611-2-5 
Shimasaki, C., 2014. Biotechnology Entrepreneurship: Starting, Managing, and Leading Biotech Companies. Academic Press Inc.

Stambler, I., 2012. A History of Life-Extensionism in the Twentieth Century. Bar-Ilan University, Ramat Gan, Israel.

Steinbock, D., 2014. The Challenges for America's Defense Innovation. 